\title{
ОСОБЕННОСТИ УПРАВЛЕНИЯ УСЛУГАМИ ГАЗОВОГО ТРАНСПОРТА И ИХ КЛАССИФИКАЦИИ
}

\section{(c) 2018 Бабаков Александр Владимирович}

кафедра экономики и управления предприятиями и производственными комплексами Санкт-Петербургский государственный экономический университет 191023, Санкт-Петербург, Садовая ул., д. 21

В работе рассматриваются особенности управления газотранспортной системой на основе анализа понятия услуг, их классификации и места газотранспортных услуг в этой сфере. Транспортная услуга по доставке газа по трубопроводу неотделима от самого товара - газа. Еще одна особенность транспортировки газа как услуги заключается в необходимости обеспечения определенного качества товара. Именно поэтому услугу транспортировки газа можно назвать товарной услугой. В статье дается определение этого понятия, его особенностей, а также влияния на имеющиеся стандарты в отрасли.

Ключевые слова: газотранспортные услуги, товарные услуги, управление услугами, классификация услуг, трубопроводной транспорт, транспортировка газа.

Основой построения и развития системы управления предприятием является анализ особенностей функционирования объекта управления: целей, принципов организации, технологии, типа производства, специфики предмета производства (товара или услуги), отраслевой и рыночной позиции, способов удовлетворения потребностей клиентов, производственной структуры.

Объектом управления в данной работе выступает предприятие, предоставляющее услуги по транспортировке газа. Поэтому целесообразно осуществлять рассмотрение особенностей управления газотранспортной системой на основе анализа понятия услуг, их классификации и места газотранспортных услуг в этой сфере.

Трактовка понятия «услуга» во времени менялась. Так, в XIX веке К. Маркс рассматривал услугу следующим образом: «...Когда деньги непосредственно обмениваются на такой труд, который не производит капитала, т.е. на непроизводительный труд, этот труд покупается как услуга. Это выражение означает вообще не что иное, как ту особую потребительную стоимость, которую доставляет этот труд, подобно всякому другому товару; но особая потребительная стоимость этого труда получила здесь специфическое название «услуги» потому, что труд оказывает услуги не в качестве вещи, а в качестве деятельности» [5]. В XX веке Ф. Котлер определяет услугу как «любую деятельность, которую одна сторона может предложить другой; неосязаемое действие, не приводящее к владению чем-либо.
Предоставление услуг может быть связано или не связано с материальными продуктами» [3]. Ему вторит другой специалист по маркетингу П. Дойль: «Услуга является действием или выгодой, ее покупатель не получает права собственности на какой-либо материальный объект» [2].

Несмотря на очевидность понятия «услуга» с достаточно длительным периодом его использования на практике, в теории не выработано единого мнения по его определению. Это связано с существенным изменением роли услуг в экономиках стран (ростом их доли вплоть до преобладания в ВВП), с их, если можно так выразиться, «эфемерностью» по сравнению с материально осязаемым товаром, со своей спецификой непосредственного удовлетворения потребности, часто без материально-вещественной формы констатации этого результата. Сложность определения услуги в том, что она может предоставляться с использованием товаров и без них.

Определения услуг заметно разнятся: это и выгоды, и полезные осязаемые действия, и результат взаимодействия, содействие удовлетворению потребностей, и даже специфический товар.

Применительно к газотранспортным услугам проявляются те же сложности определения понятия и классификации. С одной стороны, газотранспортное предприятие предоставляет услугу по транспортировке товара (газа) заказчику, являющемуся собственником этого товара (в нашем случае - ПАО «Газпром»). С другой стороны, конечный заказчик - потребитель газа - по- 
лучает конкретный товар, который использует или в производстве, или в бытовых целях. При этом газотранспортное предприятие участвует в обработке товара (т.е. формирует добавленную стоимость): поддерживает его стандартное качество, которое ухудшается по мере транспортировки газа; предоставляет товар в определенной форме - под давлением, приемлемым для промежуточных потребителей («Межрегионгаз», газораспределительные и газоиспользующие организации). Видно, что один и тот же объект, поставляемый заказчику для удовлетворения потребности, может рассматриваться, с одной стороны, как товар, а других случаях как услуга что зависит от точки зрения заказчика.

Существует множество комбинаций, начиная от преобладания продукта и заканчивая преобладанием услуги [4]: преобладание товара без услуги или включая услугу; преобладание услуги без товара или включая товар. Чтобы приблизиться к пониманию сущности услуги газотранспортных предприятий, следует обратить внимание на ее особенности, отраженные в таблице 1 , но только для «чистых услуг» (без товаpa, по крайней мере без его учета).

Если рассматривать работу газотранспортных предприятий как транспортировку газа по заказу его собственника, то все эти особенности и проблемы на них также распространяются. В связи с указанными особенностями можно отметить ряд проблем (риск-факторов) при оказании услуг, в том числе транспортных:

- невозможность корректировки качества услуги после ее оказания, несмотря на возможность контроля качества в процессе потребления. При этом потребительская оценка качества услуг определяется уже в процессе потребления (что происходит в процессе транспортировки газа по заказу ПАО «Газпром»);
- сложность определения качества услуг в связи с его неопределенностью, с субъективными факторами оказания услуг, в связи с чем происходит координация работы исполнителя - газотранспортного предприятия - и эксперта по оценке качества услуги (ПАО «Газпром»);

- невозможность создания запасов услуг для будущих продаж;

- нетранспортируемость услуг с привязкой их к определенному региону, что характерно для газотранспортных предприятий ПАО «Газпром» с заметной дифференциацией производственных мощностей по ряду признаков (износ, уровень обновления, протяженность сетей, географические и климатические условия).

С другой стороны, данные особенности определяют преимущества с точки зрения снижения рисков услуг по сравнению с производством товаров:

- снижение затрат на складирование готовой продукции (сокращение финансовых и логистических рисков);

- снижение претензий по качеству работы, сложность их предъявления и, с другой стороны, постоянный контроль потребителя в процессе производства;

- отсутствие конфликтов и тяжб по поводу прав собственности между производителем и потребителем.

Экономическое значение транспортной отрасли в России довольно высоко, как и во многих других странах, прошедших индустриальное развитие. Доля транспорта и связи в ВВП РФ колебалась между 8,4 и 8,6\%, в 2012-2016 годах [10, с. 184]. По существующим оценкам, доля собственно транспорта составляет примерно 5,5\%. Собственно, транспортная отрасль в России имеет высокое значение в большей степени в стратегическом плане, чем с точки зрения

Таблица 1. Особенности услуг в отличие от товаров («5 HЕ»)

\begin{tabular}{|l|l|l|}
\hline \multicolumn{1}{|c|}{ Свойства } & \multicolumn{1}{|c|}{ Сущность объекта } & \multicolumn{1}{|c|}{ Особенности } \\
\hline Неосязаемость & $\begin{array}{l}\text { Отсутствие материально-вещественной } \\
\text { формы, неопределенность }\end{array}$ & $\begin{array}{l}\text { Качество определяется по косвенным } \\
\text { признакам, сложность сравнения цен }\end{array}$ \\
\hline $\begin{array}{l}\text { Неотделимость произ- } \\
\text { водства и потребления }\end{array}$ & $\begin{array}{l}\text { Одновременное производство и потре- } \\
\text { вление, контроль потребителя за произ- } \\
\text { водством, региональный характер }\end{array}$ & $\begin{array}{l}\text { Постоянное взаимодействие произво- } \\
\text { дителя и потребителя, клиент влияет на } \\
\text { качество объекта }\end{array}$ \\
\hline Несохраняемость услугг & $\begin{array}{l}\text { Невозможность сохраняемости, форми- } \\
\text { рования запасов }\end{array}$ & $\begin{array}{l}\text { Недолговечность (возможно мгновен- } \\
\text { ность), неоказанные услуги - потери }\end{array}$ \\
\hline $\begin{array}{l}\text { Неопределенность } \\
\text { качества }\end{array}$ & $\begin{array}{l}\text { Зависимость качества от места, времени, } \\
\text { формы, технологии объекта, квалифика-- } \\
\text { ции персонала }\end{array}$ & $\begin{array}{l}\text { Сложность стандартизации, зависимость } \\
\text { отективных факторов, важность } \\
\text { репутации }\end{array}$ \\
\hline $\begin{array}{l}\text { Непередача собствен- } \\
\text { ности }\end{array}$ & $\begin{array}{l}\text { Право собственности на передаваемый } \\
\text { объект, отсутствует }\end{array}$ & $\begin{array}{l}\text { Удовлетворение потребности с огра- } \\
\text { ничением времени, особые правовые } \\
\text { формы контрактов }\end{array}$ \\
\hline
\end{tabular}


экономики как таковой. Единая транспортная система (как и единая энергетическая система) выступает как один из важнейших стратегических факторов единства страны, ее целостности, а задача экономии затрат на транспортные услуги и минимизации цен на них является важнейшим инструментом поддержания этого стратегического фактора. Как показывает статистика, газотранспортные услуги занимают наибольшую долю в сфере транспортных услуг РФ. Так, в 2015-2016 гг. трубопроводный транспорт занимал $48 \%$ всего грузооборота транспортной отрасли РФ - 2,5 трлн. т-км в 2016 г. (рис. 1), при том что на такой важный вид транспорта, как железнодорожный, пришлось 45\% [6, с. 439].

Трубопроводный транспорт в РФ выполняет задачи транспортировки газа (1,2 трлн. т-км в 2016 г.- 47,5\%) и нефти $(52,5 \%)$ [6, с. 440]. Протяженность газопроводов (179 тыс. км на 2016 г.) значительно больше нефтепроводов (71 тыс. км) [6, с. 444]. Высокая значимость трубопроводного транспорта подтверждается также самым высоким объемом инвестиций среди других подотраслей транспорта - 715,4 млрд. руб. в 2015 году, или $58 \%$ в отрасли транспорта (рис. 2). На втором месте - железнодорожный транспорт с меньшим в 2 раза объемом инвестиций (340 млрд. руб.-27,5\%) [6, с. 19].

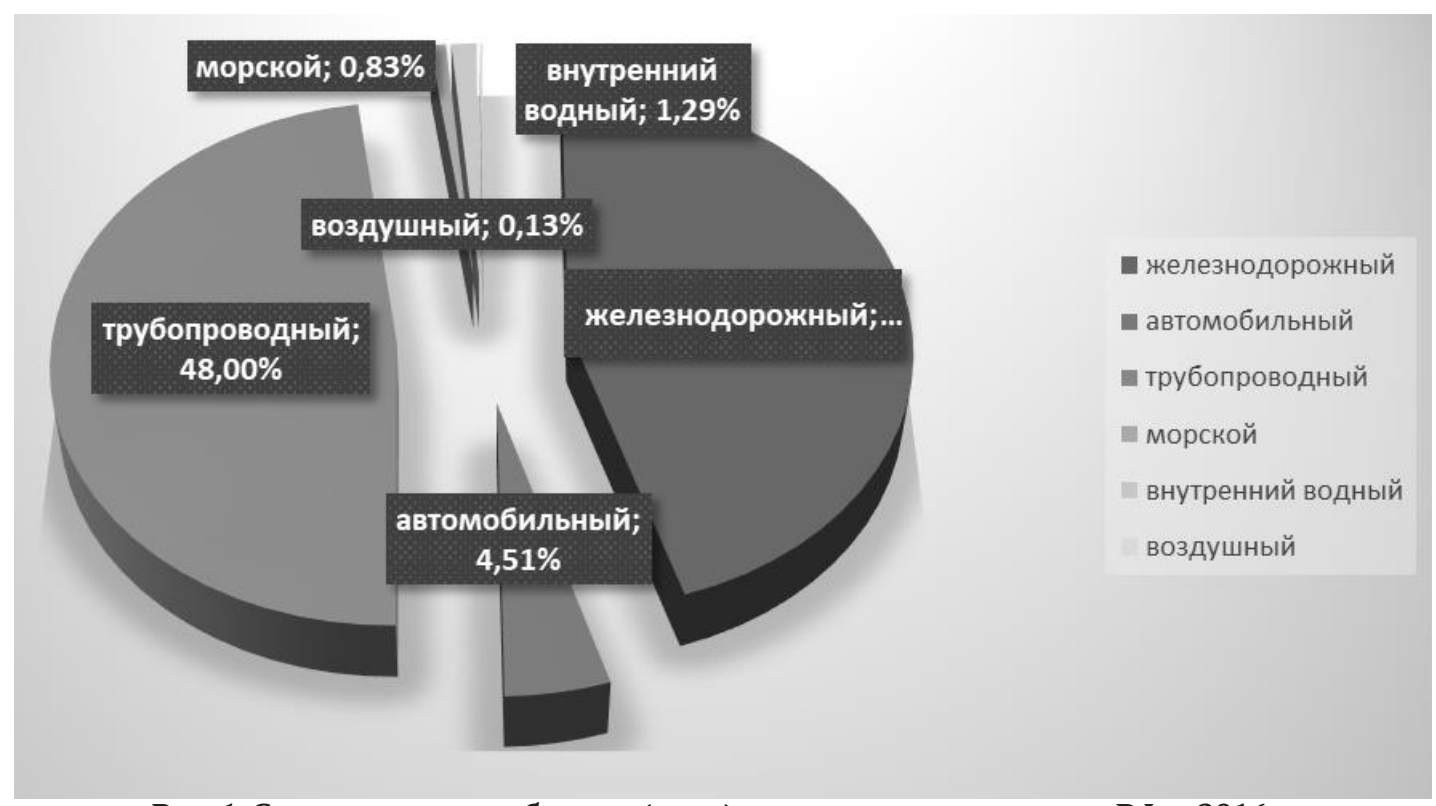

Pис. 1. Структура грузооборота (т-км) по видам транспорта в РФ в 2016 г.

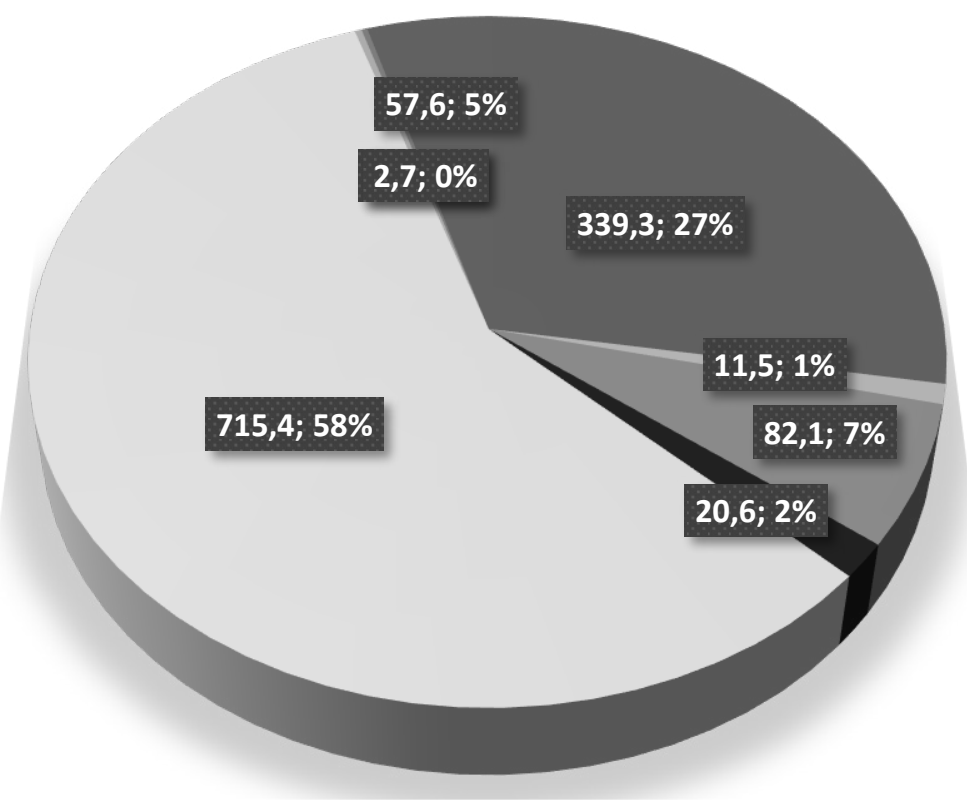

шелезнодорожный транспорт

автомобильный (автобусный)
пассажирский транспорт,
подчиняющийся расписанию

городской электрический транспорт

ш автомобильный грузовой транспорт

транспортирование по
трубопроводам

морской транспорт

в внутренний водный транспорт

Puc. 2. Структура инвестиций в основной капитал в транспорте РФ 
О хорошем финансовом состоянии трубопроводной отрасли говорят также ее финансовые показатели: за 2015 год сальдированный результат предприятий этой отрасли составил 145 млрд. руб. (рис. 3), что ставит ее по этому показателю на первое место среди транспортных подотраслей Кроме того, в подотрасли наименьшей является доля убыточных предприятий $-16,8 \%$ ) [6, c. 26].

Трубопроводы занимают второе место по плотности среди отраслей транспорта РФ [9, с. 445].

Все это говорит о высокой значимости трубопроводного транспорта в РФ, хотя для отдельных стран значимость трубопроводного транспорта еще выше (табл. 2). Так, в Азербайджане и Армении по грузообороту трубопроводный транспорт занимает соответственно $71,7 \%$ и $64,2 \%$, однако эти страны не сравнимы с РФ по территории, а Армения выступает только транзитером нефти и газа [6, с. 105].

Значимость транспортных услуг в последнее время повышается в рамках роста значимости отрасли услуг в целом, обусловленного следующими факторами:

1. Глобализация сферы услуг во всем мире; Долгое время эта сфера была локализована в отдельных странах в силу тесной взаимосвязи производителя и потребителя услуг, однако в начале XXI века в связи с научно-техническими достижениями многие виды услуг интегрируются в мировую экономику: телекоммуникации, информатика, программирование, финансы, страхование, образование, туризм, автосервис и т.д. (следует отметить, что транспортные услуги по доставке газа стали интернациональными еще во второй половине прошлого века).

2. Усиление разделения труда, которое коснулось не только производственных отраслей (промышленность, сельское хозяйство), но и

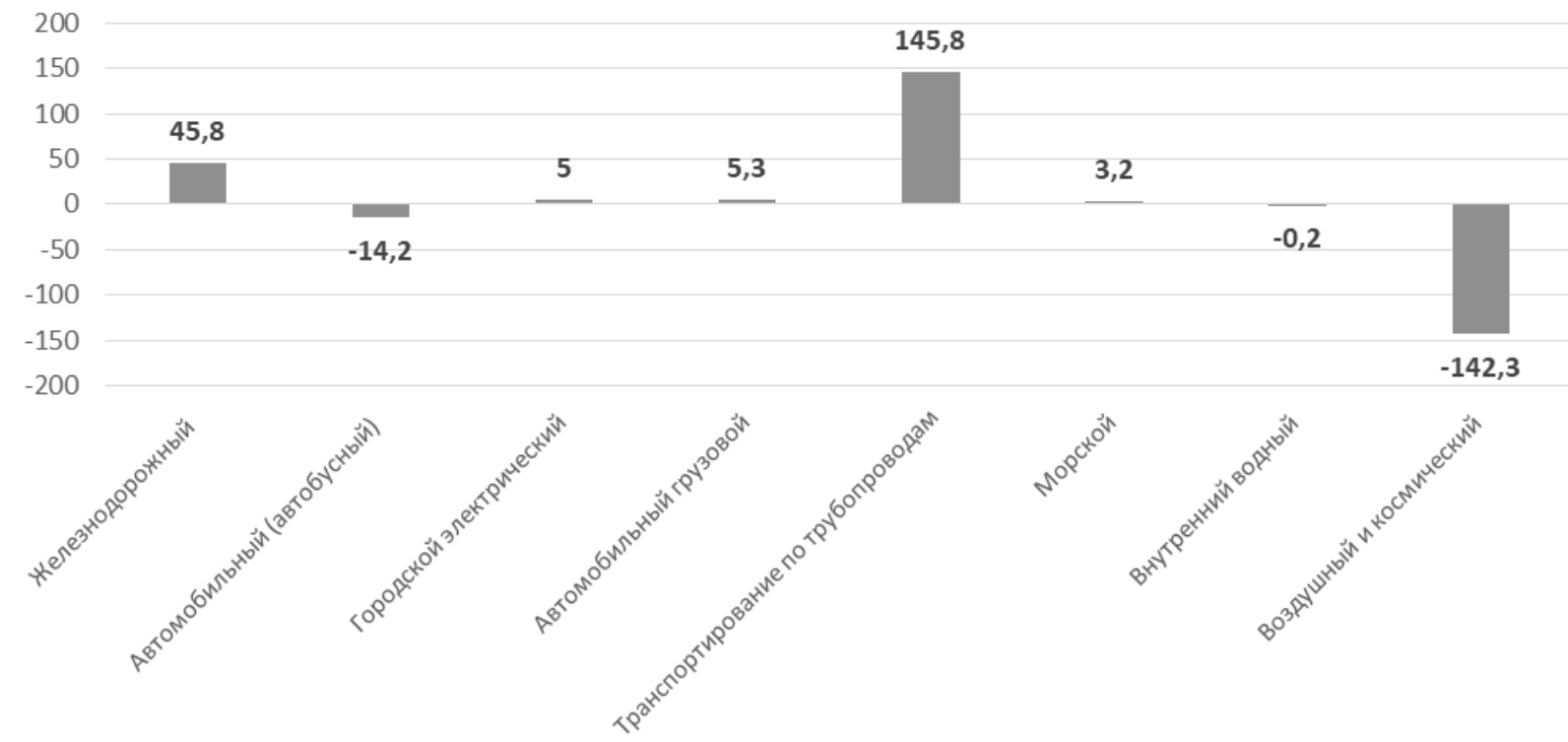

Puc. 3. Сальдированный финансовый результат деятельности организации транспорта, млрд. руб.

Таблица 2. Структура видов транспорта в общем грузообороте,\%

\begin{tabular}{|c|c|c|c|c|c|c|c|}
\hline & Год & $\begin{array}{c}\text { Железнодо- } \\
\text { рожный }\end{array}$ & $\begin{array}{c}\text { Автомо- } \\
\text { бильный }\end{array}$ & $\begin{array}{c}\text { Трубопрово- } \\
\text { дный }\end{array}$ & Морской & $\begin{array}{c}\text { Внутренний } \\
\text { водный }\end{array}$ & Воздушный \\
\hline Россия & 2015 & $\mathbf{4 5 , 3}$ & $\mathbf{4 , 6}$ & $\mathbf{4 8}$ & $\mathbf{0 , 8}$ & $\mathbf{1 , 2}$ & $\mathbf{0 , 1}$ \\
\hline Азербайджан & 2014 & 7,9 & 15,5 & $\mathbf{7 1 , 7}$ & 4,4 & - & 0,5 \\
\hline Армения & 2014 & 18,6 & 17,2 & $\mathbf{6 4 , 2}$ & - & - & 0,05 \\
\hline Беларусь & 2014 & 34,3 & 20,2 & $\mathbf{4 5 , 4}$ & - & 0,04 & 0,05 \\
\hline Германия & 2013 & 22,7 & 61,6 & $\mathbf{3 , 7}$ & $\ldots$ & 12,1 & $\ldots$ \\
\hline Казахстан & 2014 & 50,6 & 28,1 & $\mathbf{2 0 , 9}$ & 0,4 & 0 & 0,1 \\
\hline Китай & 2014 & 14,8 & 32,8 & $\mathbf{2 , 3}$ & 30,1 & 19,8 & 0,1 \\
\hline СшА & 2012 & 30,7 & 47 & $\mathbf{1 6 , 6}$ & $\ldots$ & 5,7 & $\ldots$ \\
\hline
\end{tabular}


сферы услуг.

3. Усиление международной конкуренции, которое идет не только по различным отраслям и видам продукции, но по всему циклу «исследования - производство - сбыт - послепродажное обслуживание», последний сервисный этап как раз относится к сфере услуг. Промышленные компании все больше расширяют сервисный бизнес с улучшением качества обслуживания потребителей, использованием новых методов расширения сферы обслуживания (франчайзинг), причем конкурентоспособные компании получают доступ к международным рынкам и наращивают экспорт своих услуг.

4. Возможность использования разрыва во времени производства услуги и ее потребления в связи с новыми техническими возможностями, возможность накопления, хранения, передачи услуг на расстояние, потребления разными способами. Это сделало ряд услуг объектами международной торговли.

5. Изменение структуры услуг в мировом масштабе: снижение доли традиционных видов услуг (торговых, бытовых, оздоровительных) и рост доли наукоемких профессиональных услуг, связанных с инновациями (телекоммуникации, образование, медицина на основе биотехнологий). Очевидно, с инновационными технологиями тесно связано развитие транспорта, в том числе трубопроводного.

Начиная со второй половины XX века сфера услуг стала доминирующим сектором, обогнав сектор производства и строительства. В 2017 году доля сферы услуг составила в США 80,2\%, Великобритании - 80,4\%, во Франции - 79\%, в Германии и Японии - 69\% (в Люксембурге эта доля составляет даже 85\%) [11, с. 86]. В 2016-2017 гг. доля сферы услуг в ВВП РФ составляла 62\% [10, с. 183-184], по сравнению с 1990 годом эта доля существенно выросла (с 33\%). Доля численности занятых в сфере услуг в общей численности занятых еще выше - 65\% [6, с. 114]. В 1990 г. доля занятых в сфере услуг в России составляла $38 \%$, в 2000 г. $-55 \%$.

Для понимания места трубопроводного транспорта в отрасли транспорта, сфере услуг и в народном хозяйстве требуется рассмотрение классификации услуг, что послужит качественной характеристикой рассматриваемого объекта. При этом следует учитывать, что как терминологическое понятие «услуги» до сих пор не устоялось из-за быстрого развития сферы услуг, расширения их разнообразия и постоянного обновления, так и классификация услуг не приняла своей законченной формы несмотря на наличие достаточно фундаментальных подходов к классификации услуг, выразившейся в появлении ряда международных стандартов - классификаторов, без которых невозможна международная торговля. Для различных целей - научных, практических, исторических, фискальных, целей отраслевой и продуктовой стандартизации используются различные виды классификаций (табл. 3).

Последний признак классификации оказывается важным для исследуемого нами объекта - транспортных услуг по доставке потребителям газа. Эти транспортные услуги потребители самостоятельно не могут выполнить в отличие от других видов транспортных услуг (например, самовывоз на своем автомобильном транспорте). Транспортная услуга по доставке газа по трубопроводу неотделима от самого товара - газа. Если уточнить последнюю классификацию, то она будет выглядеть следующим образом (табл. $4)$.

Особенность транспортировки газа, как услуги, заключается в том, что при поставке потребителю должно быть обеспечено определенное качество товара, который регулируется рядом нормативных документов [1]. Применительно к транспорту газа по магистральным газопроводам - основным требованием к качеству выступает обеспечение однофазного состояния газа на всем протяжении газопровода, достаточной надежности и эффективности транспортировки газа, минимизация потерь. Несоблюдение требования по однофазному состоянию газа может привести к серьезным потерям с переходом транспортируемого газа в другие фазы: в жидкое (вода и углеводородный конденсат) и твердое состояние (лед и газовые гидраты), следствием чего является рост гидравлического сопротивления трубопроводов (и их износа), не говоря о потере качества самого газа. Требования к качеству газа, особенно к однофазовому состоянию, обусловлено огромной протяженностью газопроводов из Крайнего Севера и Сибири в западную часть России и в Европу.

Поскольку требования к качеству газа основываются на ряде параметров: химический состав газа, минимальное значение влажности (влагосодержания) и сероводородов (содержание меркаптановой серы не более 36 мг/куб. м) и 
Таблица 3. Классификации услуг

\begin{tabular}{|c|c|c|}
\hline $\begin{array}{c}\text { Признак } \\
\text { классификации }\end{array}$ & Виды & Примеры \\
\hline \multirow{2}{*}{$\begin{array}{l}\text { 1.Функциональные } \\
\text { потребности }\end{array}$} & - материальные & ЖКХ, общественное питание, транспорт, наука \\
\hline & - нематериальные & образование, культура, туризм \\
\hline \multirow{4}{*}{$\begin{array}{l}\text { 2. Роль в воспроиз- } \\
\text { водстве }\end{array}$} & - производственные & $\begin{array}{l}\text { разработка технологий, инжиниринг, ремонт и техническое } \\
\text { обслуживание оборудования и производственных помеще- } \\
\text { ний и т.д. }\end{array}$ \\
\hline & - распределительные & транспорт, связь, логистика \\
\hline & - обменные & финансы, лизинг, торговля \\
\hline & - потребительские & $\begin{array}{l}\text { услуги, используемые в домашнем хозяйстве, развлечениях, } \\
\text { культурное потребление, информация для личных целей } \\
\text { (СМИ, образование) }\end{array}$ \\
\hline \multirow{2}{*}{$\begin{array}{l}\text { 3.Экономическая } \\
\text { цель }\end{array}$} & - коммерческие услуги & $\begin{array}{l}\text { с целью получения прибыли (транспорт, связь), в том числе } \\
\text { услуги, оплачиваемые производителем или заказчиком }\end{array}$ \\
\hline & - некоммерческие & $\begin{array}{l}\text { удовлетворение потребностей (культура, государственная } \\
\text { медицина, образование) }\end{array}$ \\
\hline \multirow{2}{*}{$\begin{array}{l}\text { 4. Средство предо- } \\
\text { ставления услуг }\end{array}$} & $\begin{array}{l}\text { - с доминированием } \\
\text { технических средств }\end{array}$ & транспорт, связь, ЖКХ \\
\hline & $\begin{array}{l}\text { - с доминированием } \\
\text { человеческого труда }\end{array}$ & консалтинг, юридические услуги, клининг \\
\hline \multirow{4}{*}{$\begin{array}{l}\text { 5. Виды потреби- } \\
\text { телей }\end{array}$} & $\begin{array}{l}\text { - производственные } \\
\text { потребители (бизнес) }\end{array}$ & $\begin{array}{l}\text { грузовой транспорт для юридических лиц, ремонт и тех- } \\
\text { ническое обслуживание оборудования и производственных } \\
\text { помещений, оптовая торговля }\end{array}$ \\
\hline & $\begin{array}{l}\text { - население (домашние } \\
\text { хозяйства) }\end{array}$ & $\begin{array}{l}\text { пассажирский транспорт, розничная торговля, связь для } \\
\text { личного потребления }\end{array}$ \\
\hline & - менеджеры & консалтинг, финансы, лизинг \\
\hline & - государство & $\begin{array}{l}\text { фундаментальные НИР, обслуживание государственных } \\
\text { органов управления (информация, образование, связь) }\end{array}$ \\
\hline \multirow{2}{*}{$\begin{array}{l}\text { 6. Роль в формиро- } \\
\text { ваниипотребитель- } \\
\text { ной стоимости }\end{array}$} & $\begin{array}{l}\text { - создание новой потре- } \\
\text { бительной стоимости }\end{array}$ & транспорт, связь, консалтинг \\
\hline & - ее восстановление & Ремонт различных технических средств \\
\hline \multirow{2}{*}{$\begin{array}{l}\text { 7. Субъект оказания } \\
\text { услуги }\end{array}$} & - государственные & государственная медицина, образование, транспорт \\
\hline & - негосударственные & частные транспортные услуги \\
\hline \multirow{2}{*}{$\begin{array}{l}\text { 8. Период оказания } \\
\text { услуги }\end{array}$} & - предпродажные & $\begin{array}{l}\text { реклама, дегустация, испытания, корректировка характери- } \\
\text { стик товара под потребности покупателя }\end{array}$ \\
\hline & - послепродажные & $\begin{array}{l}\text { монтаж, сервисное обслуживание, страхование, поставка } \\
\text { запасных частей }\end{array}$ \\
\hline \multirow[b]{2}{*}{$\begin{array}{l}\text { 9. Вид создаваемого } \\
\text { продукта }\end{array}$} & - чистые & $\begin{array}{l}\text { без связи с товарами в натурально-вещественной форме: } \\
\text { страховые, банковские, консалтинговые, образовательные }\end{array}$ \\
\hline & - сопутствующие & $\begin{array}{l}\text { сопутствующие продаваемым товарам: транспортиров- } \\
\text { ка (доставка) товаров, в том числе газа по трубопроводу; } \\
\text { сервисное (гарантийное, ремонтное) обслуживание постав- } \\
\text { ляемого оборудования }\end{array}$ \\
\hline
\end{tabular}

Таблица 4. Классификация услуг по степени сочетания услуги с товаром, которому сопутствует услуга

\begin{tabular}{|l|l|}
\hline \multicolumn{1}{|c|}{ Виды } & \multicolumn{1}{c|}{ Примеры } \\
\hline \multirow{2}{*}{ Доминирование услуги } & Чистая услуга (без товара) \\
\cline { 2 - 2 } Доминирование товара & $\begin{array}{l}\text { Услуга с товаром (стоимость услуг выше стоимости товара) - эксплуатация пе- } \\
\text { обой или фототехники (стоимость обслуживания выше стоимости купленного } \\
\text { обония за весь срок жизни) }\end{array}$ \\
\hline & $\begin{array}{l}\text { Товар с услугой (стоимость товара выше стоимости услуг) - транспортировка } \\
\text { насыпных грузов, пассажиров }\end{array}$ \\
\cline { 2 - 2 } $\begin{array}{l}\text { Ровар с услугой, обеспечивающей качество товара - транспортировка газа, в } \\
\text { уомуги числе сжиженного; сервисное обслуживание оборудования }\end{array}$ \\
\hline
\end{tabular}


др., то в процессе транспортировки газа продолжаются производственные процессы по сепарации, осушке, очистке от углеводородов и сероводородов (а также агрессивных и механических примесей), одоризации“.

Именно поэтому услугу по транспортировке газа можно назвать не просто производственной, но и товарной услугой (газ, подаваемый потребителям, называется «товарным газом»). Это подтверждается тем, что в структуре себестоимости транспортировки газа доля амортизации технологического оборудования превышает 50\%, что говорит о существенной технической, а значит, и производственной составляющей в оказании данных услуг. Кроме того, в себестоимость транспорта газа включаются потери от брака, что также подтверждает товарность этой услуги, неразрывность транспортной услуги от товарного газа. Значимость товарной услуги по транспортировке газа в конечном результате себестоимости поставляемого газа потребителям - заметна при сравнении себестоимости по различным направлениям формирования конечной себестоимости: так, по данным ПАО «Газпром», себестоимость добычи газа в 2017 г. составила 845 руб. / 1000 куб. м, а себестоимость его транспортировки 64,7 руб. / 1000 куб. м, то есть около 8\% от затрат на добычу газа [12]. Более того, неразрывность товарной услуги по транспортировке газа и самого товарного газа подтверждается методикой расчета НДПИ на газ, в состав которого включается величина показателя, характеризующего расходы на транспортировку газа (несмотря на то, что ПАО «Газпром» выступает против включения этой составляющей).

Таким образом, в рамках классификации услуг можно предложить новый вид услуги - товарной услуги, особенностями которой являются:

- неразрывность товара и услуги;

- невозможность существования услуги без товара;

- большое значение услуги в обеспечении качества товара, его сохранении и повышении;

- продолжение производственного процесса по производству товара при его поставке;
- значимая доля стоимости услуги в цене товара.

Выявление нового класса «товарных услуг» связано с последними тенденциями развития сферы услуг: «Главной особенностью развития сферы услуг в настоящее время является резкое усиление ее технологической и воспроизводственной взаимозависимости с материальным производством, глубокое взаимопроникновение услуг во все виды жизнедеятельности общества» [7].

Выделение товарной услуги предполагает изменение подходов к организации управления ее производством (интеграция процессов управления производством товаров и услуг - интегрированная система менеджмента), к формированию себестоимости и цен в суммарной стоимости товаров и услуг, неразделимых (по товару и услуге) для потребителя, рост доли стоимости собственно услуги в цене товара при повышении требований к качеству товара, усложнение управления производством товарной услуги вследствие роста его технической оснащенности. Формирование товарной услуги в рамках газотранспортной системы и повышенные требования к качеству газа при его транспортировке реализованы в стандартах ООО «Газпром трансгаз Москва» по интегрированной системе менеджмента. Так, в СТО ГТМ 13.1-10015 по ИСМ газотранспортных предприятий сформулированы следующие положения:

«7.5.5.1. Специфика транспорта газа - непрерывное производство. Данная деятельность не предполагает действия по обслуживанию.

7.5.5.2. Непрерывность транспорта газа в большинстве случаев не позволяет привести поступивший от поставщика несоответствующий газ в соответствующее состояние. В отдельных случаях по согласованию с соответствующим департаментом ПАО «Газпром» осуществляются действия по приведению газа в соответствующее состояние».

При рассмотрении газотранспортной услуги в таком ракурсе становится понятной необходимость выделения услуг по транспортировке газа в отдельный класс товарных услуг с отражением этого вывода в стандартах по класси-

\footnotetext{
* Одоризация - производственный процесс добавки в состав газа одоранта (специального вещества - этилмеркаптана или смеси природных меркаптантов), который должен соответствовать ряду требований: обладание характерным запахом для своевременного обнаружения утечки газа в целях безопасности, отсутствие вреда для людей и последствий для коррозии металла (труб, газового оборудования), физическая и химическая устойчивость в парообразном состоянии, концентрированность.
} 
фикации видов экономической деятельности, продукции и услуг. Выделение в отдельный класс «товарных услуг» транспортировки газа затрагивает не только данный вид услуг, но и ряд других, подверженных последним тенденциям интеграции производства и обслуживания, появления новых технологий и новых технологичных видов услуг, развития информатизации и коммуникаций, усиления значимости сферы услуг (транспорт нефти и нефтепродуктов, программное обеспечение для компьютеров и серверов, аутсорсинг при сервисном обслуживании поставленного технологического оборудования). Таким образом, может быть обозначена проблема целесообразности корректировки стандартных классификаторов, в том числе ОК 029-2014 (КДЕС Ред.2) «Общероссийский классификатор видов экономической деятельности» и ОК 034-2014 (КПЕС 2008) «Общероссийский классификатор продукции по видам экономической деятельности». Европейскими аналогами общероссийских классификаторов выступают соответственно «Статистическая классификация экономической деятельности Европейского Сообщества» (NACE Rev. 1, КДЕC Ред.1) и «Статистическая классификация продукции по виду экономической деятельности в Европейском экономическом сообществе» (СРА, КПЕС).

Сделанные выше выводы о проявлении транспорта газа как товарной услуги говорят о несоответствии сложившихся стандартов классификации экономической сущности группировки товаров и услуг: в традиционных транспортных услугах (железнодорожных, автомобильных воздушных, водных) производство товара и собственно транспортной услуги четко разделено как в отраслевом - производственном, так и организационно-правовом аспекте (качество перемещаемого товара не меняется, производственные процессы по сохранению или повышению качества товара в процессе транспортировки не осуществляется). С точки зрения необходимости кодификации товаров и услуг, унификации технических нормативов (технического регулирования), идентификации цен, налоговых и таможенных сборов данные стандарты выполняют свои функции. Но с точки зрения экономического сравнительного анализа отраслей и секторов, стран и компаний, задач по оптимизации систем управления данная классификация не соответствует научным требованиям адекватности классифицируемых объектов целям исследования. Выделение класса товарных услуг, в частности для трубопроводных транспортных систем, их отделение от традиционных транспортных было бы более корректным для научно-аналитических и статистических задач.

\section{Библиографический список}

1. ГОСТ 5542-87 «Газы горючие природные для промышленного и коммунально-бытового назначения. Технические условия»; ГОСТ 27577-2000 «Газ природный топливный компримированный для двигателей внутреннего сгорания. Технические условия»; ОСТ 51.40-93 «Газы горючие природные, поставляемые и транспортируемые по магистральным газопроводам. Технические условия».

2. Дойль П. Маркетинг-менеджмент и стратегии. 3-е изд. Санкт Петербург. 2003. С. 245.

3. Котлер Ф. Маркетинг. Менеджмент: анализ, планирование, внедрение, контроль. Санкт Петербург. 1998. С. 638.

4. Лободенко Л. К., Окольнишникова И.Ю. Теоретические подходы к определению сущности и классификации рекламных услуг // Вестник Южно-Уральского государственного университета. Серия: Экономика и менеджмент. 2011. № 18. С. 123-130.

5. Маркс К., Энгельс Ф. Сочинения. Т. 26., Ч. 1. 2-е изд. С. 413.

6. Транспорт и связь в России. 2016: Стат. сб. Москва. 2016. 114 с.

7. Подачина Л.И., Суслова Ю.Ю. Современные подходы к классификации и оценке услуг, влияющих на параметры качества жизни // Проблемы современной экономики. 2012. № 4 (44). С. 347-351.

8. Разомасова Е.А. Место сферы услуг в российской экономике // Сибирская финансовая школа. Экономика. 2010. № 5 (82). С.40-44.

9. Российский статистический ежегодник. 2017: Стат. сб. / Росстат. М., 2017. 686 с.

10. Россия в цифрах. 2017: Крат. стат. сб. / Росстат. М., 2017. 513 с.

11. Россия и страны мира. 2016: Стат. сб. / Росстат. М., 2016. 381 с.

12. Финансово-экономическая политика ОАО «Газпром». Материалы пресс-конференции: электронный ресурс. СПб., 2018. URL: https://www.gazpromvideo.ru/fileadmin/press/2018/0628/presentation_28062018_ru.pdf. 